\title{
Managerial entrenchment and corporate social responsibility engagement: the role of economic policy uncertainty
}

\author{
Sammy G. Muriithi ${ }^{1}$ - Bruce A. Walters ${ }^{2}$ - William R. McCumber ${ }^{3}$. \\ Luis R. Robles Sr. ${ }^{4}$
}

Accepted: 8 March 2021 / Published online: 23 March 2021

(c) The Author(s), under exclusive licence to Springer Science+Business Media, LLC, part of Springer Nature 2021

\begin{abstract}
The behavioral theory of corporate governance is employed to investigate the relationship between managerial entrenchment and corporate social responsibility (CSR) engagement. Effective corporate governance is argued to reduce managerial entrenchment, thereby increasing CSR engagement. The role of economic policy uncertainty (EPU) is investigated as a moderating variable in this relationship, such that high levels of EPU will increase the impact of entrenchment on CSR engagement. These arguments are supported using a panel of 386 US firms from 2011 to 2018 representing 3,088 firm-year observations in a variety of industries. In supplementary analysis, the CSR measure is disaggregated in order to provide further insight regarding these relationships as they pertain to the individual CSR dimensions under study. Findings inform research regarding the entrenchment-CSR link in particular environmental contexts. Practical implications include potential governance guidelines for boards of directors; stakeholder management given the policy environment; and the impact of government decisions as they affect policy uncertainty, firm actions, and CSR engagement.
\end{abstract}

Keywords Managerial entrenchment - Corporate social responsibility · Economic policy uncertainty $\cdot$ Behavioral theory of corporate governance

\section{Introduction}

Research interest in the link between corporate governance (CG) and corporate social responsibility (CSR) continues to grow (e.g. Gennari \& Salvioni, 2019; Jeong, 2020). Academics and practitioners alike consider the role that governance

Sammy G. Muriithi

smuriithi@uco.edu

Extended author information available on the last page of the article 
plays in determining CSR to be important, and such interest has been accelerated in part by the rise of corporations that engage in socially responsible activity (Flammer et al., 2019). Increasing pressure for managers to enhance social value beyond that required by legislation motivates them to pursue socially responsible initiatives alongside financial objectives (Porter \& Kramer, 2006). In this light, Jo and Harjoto (2011) contend that effective CG keeps managerial entrenchment in check, thereby managing the interests of multiple stakeholders and resolving the conflicts of interest between shareholders and non-investing stakeholders. Corporate governance objectives are met by reconciling the interests of owners, managers, and all other stakeholders of the corporation, allowing it to meet its long-term capital needs, retain the confidence of financiers, and use the obtained capital proficiently (Jamali et al., 2008). These interests are generally best reconciled when governance structures restrain managerial entrenchment in favor of a more even balance of power (Bebchuk et al., 2009).

There is a wide literature reflecting conceptualizations of CSR over the years. Friedman (1970) defined CSR as conducting business in accordance with shareholders' desires, which are generally making as much money as possible while conforming to basic rules of society, law, and ethical custom. Later definitions expanded upon Friedman's (1970) definition to reflect 'doing good' for the broader society and environment. Some of these definitions include consideration and response to issues beyond narrow economic, technical, and legal requirements (Davis, 1973); economic, legal, ethical, and discretionary expectations of society (Carroll, 1979); corporations' obligation to work for social betterment (Frederick, 1986); appropriate business behavior and outcomes resulting from the integrative nature of business and society (Wood, 1991); voluntary corporate actions designed to improve social conditions (Mackey et al., 2007); and actions to reduce externalized costs or to avoid distributional conflicts (Heal, 2005). Some authors have gone further and attempted to differentiate between corporate social performance (CSP) and corporate social responsibility (CSR). Wood (1991) suggests that CSP represents an organization's responses to expectations and demands of CSR, while Barnett (2007, p. 797) refers to CSR as "corporate investments that, over time, aggregate into certain CSP postures." We treat CSR and CSP as interrelated constructs (Le et al., 2015) under the umbrella of CSR. We adopt the definition of McWilliams and Siegel (2001, p. 117): "actions that appear to further some social good, beyond the interest of the firm and that which is required by law."

Literature investigating the entrenchment-CSR relationship has often focused on the influence of firm-level factors on managerial behavior, and consequently, firm outcomes (e.g. Arora \& Dharwadkar, 2011; Barnea \& Rubin, 2010; Jo \& Harjoto, 2011; Malik, 2015; Surroca \& Tribó, 2008). Recently, García-Sánchez et al. (2020) demonstrate that managerial entrenchment may not only moderate the relationship between CSR performance and earnings management, but also may decrease the alignment between CSR disclosure and performance. Kachouri et al. (2020) investigated the influence that gender diversity on the board and top management team may have on the relationship between managerial entrenchment and CSR. 
The relationship was found to be more strongly positive when the number of female directors was higher.

A number of other studies have explored these issues in the light of national and institutional contexts. Surroca et al. (2020) investigate whether firms' simultaneous adoption of managerial entrenchment provisions and CSR reinforces or undercuts one another in influencing firm financial performance, concluding that the institutional framework has a strong influence on their combined effect. Salehi et al. (2020) examine the effect of managerial entrenchment on firm CSR in an Iranian context, finding a positive relationship between the two. Despite the important insights gained through the named studies, institutional contexts harbor an array of variables that play an important role in firm decision-making processes.

An institutional variable that has gained increased attention from scholars of managerial behavior in a variety of economic contexts is economic policy uncertainty (EPU) — uncertainty stemming from the policy environment. The policy environment is "the set of laws, regulations, administrative procedures and policies formally sanctioned by the government that impact on a firm's profitability by altering its costs or revenues" (Delios \& Henisz, 2003, p. 229). EPU has risen globally due to factors such as the ongoing U.S.-China trade dispute, the COVID-19 pandemic (Altig et al., 2020), exit of the U.K. from the European Union (Nilavongse et al., 2020), and other political and geopolitical factors. Studies suggest EPU affects firmlevel outcomes such as asset returns (Brogaard \& Detzel, 2015), firm-level investment (Chen et al., 2019; Gulen \& Ion, 2016; Kang et al., 2014), quality of financial reporting and firm value (Yung \& Root, 2019), firm performance (Muriithi et al., 2020), firm acquisitiveness (Nguyen \& Phan, 2017), innovation activities (Bhattacharya et al., 2017), the cost of external financing (Gilchrist et al., 2014), and cash holdings (Phan et al., 2019). Yung and Root's (2019) investigation of EPU's influence on earnings management supported the claim that higher EPU leads to low-quality financial reporting that damages firm value. These results tended to hold despite national culture and other country-level factors as well as general economic uncertainty. The foregoing suggests the potential for EPU to exhibit a pervasive effect on a variety of managerial behaviors and organizational outcomes.

EPU is a relatively understudied but increasingly important aspect of uncertainty (Baker et al., 2016). No study to our knowledge has investigated the impact of EPU on the entrenchment-CSR relationship. This paper takes a step in bridging this gap by investigating EPU as a potential moderator of the relationship between managerial entrenchment and CSR engagement. Generally speaking, uncertainty concerns the rate and unpredictability of changes in a firm's environment (Dess \& Beard, 1984), and is important in managerial decision-making (Hadani et al., 2017). Predictable environments are often more stable and munificent (Dess \& Beard, 1984; Keats \& Hitt, 1988; Pfeffer \& Salancik, 1978). Under high uncertainty, cause-effect relationships are more difficult to discern, requiring new strategies and ways of organizing to cope with a more complicated landscape (Tan \& Tan, 2005).

The "homo economicus" perspective proposes that managers are selfish and primarily interested in maximizing their own outcomes (Mazar \& Ariely, 2006). Under low EPU, investment outcomes are easier to predict; and less entrenched managers may find CSR engagement satisfies shareholders (Cespa \& Cestone, 2007), 
increases managers' personal rewards, and protects their positions in the firm (Milliken \& Lant, 1991). Entrenched managers, however, may tend to maximize their perquisite consumption when EPU is low, given the relative predictability of investment outcomes and the protections derived from entrenchment (Barnea \& Rubin, 2010). But as EPU rises, the payoff expected from decisions is increasingly difficult to predict, and the likelihood of not meeting desired goals is higher regardless of entrenchment. Failure to meet performance goals may draw the attention of stakeholders, threatening managers' positions, wealth, power, and prestige if firm outcomes fall below expectations. In this case, entrenched managers with leverage in decision-making may enhance relationships with various stakeholders to avoid being replaced, ward off corporate raiders, and reduce adverse scrutiny from activist stakeholders (Frooman, 1999; Henriques \& Sadorsky, 1999; Pagano \& Volpin, 2005; Reid \& Toffel, 2009; Surroca \& Tribó, 2008). CSR engagement may be thus be viewed as a way to reduce risk in response to pressures. Koh et al. (2014) found evidence that such insurance-like benefits may add value to firms. On the other hand, a lack of managerial entrenchment is expected to garner different behaviors. Given a higher likelihood of not meeting expectations when EPU is high, managers without the protections of entrenchment may economize on CSR initiatives to avoid adverse scrutiny from shareholders and the market for takeovers (Shelley, 2006). It is noteworthy that these perceptions might be particularly acute among managers operating in liberal market economies (e.g. western economies) where governance structures reward short-term performance. Such structures can lead managers to employ myopic perspectives that drive resources away from projects with long-term payoffs (Gourevitch \& Shinn, 2005).

The study's findings indicate that EPU is indeed a moderator of the relationship between managerial entrenchment and CSR engagement. When EPU is low, CSR engagement tends to decrease as the level of entrenchment rises. However, when EPU is high, the negative effect of entrenchment on CSR engagement is diminished. In what follows, theoretical arguments for the influence of entrenchment on CSR engagement are presented. An exogenous measure of EPU is described, and it is posited to moderate the impact of entrenchment on CSR engagement. Then the sample and methodology are presented, followed by results, discussion, and organizational implications. The results also include supplementary analysis of individual CSR components, encouraging future investigations of each component in light of EPU and entrenchment.

\section{Theory and hypotheses}

\subsection{Behavioral theory of corporate governance}

Traditional CG discourse is largely grounded in economic theories that emphasize how rational, self-interested agents pursue their own individual goals. This research proposes the adoption of monitoring and incentive mechanisms that shift agent behavior into alignment with principals (e.g. Jensen \& Meckling, 1976; Tversky \& Kahneman, 1978). These perspectives conspicuously ignore the 
social and institutional contexts that can significantly influence agent behavior. The behavioral theory of corporate governance, suggested by Westphal and Zajac (2013), aids in overcoming these weaknesses by recognizing that governance issues are broader than the mere pursuit of individual agency. These authors propose that managerial agency is socially situated and socially constituted. Socially situated agency relates to "the relevance of a corporate leader's social surroundings in understanding his/her actions" (Westphal \& Zajac, 2013, p. 610). This implies that managers are confronted with a set of social relationships, networks, and institutions that impact their individual agency (Kaczmarek, 2017).

Socially constituted agency, on the other hand, “...emphasizes that what an individual senses, considers, and acts upon all stem from a process of interpretation that is fundamentally social and fundamentally based on the multiplex roles and identities of that individual, which themselves are based on prior socialization and other personal experiences or characteristics" (Westphal \& Zajac, 2013, p. 624). Managers' cumulative personal experiences determine what they regard as possible or realistic in a given situation, and thereby shape their individual agency (Kaczmarek, 2017). The social context and individual managers' interpretation of the institutional context are therefore recognized as fundamentally important guides to managerial behavior and action. In line with the behavioral theory of corporate governance, it is surmised that managerial decision-making will be informed by individual factors (e.g. personality traits, experience, selfinterest), as well as factors within the institutional environment. This study investigates one factor within the environment: economic policy uncertainty.

As stated earlier, CG mechanisms reconcile the interests of owners, managers, and other corporate stakeholders so that the firm can secure long-term capital needs, retain the confidence of financiers, and use the obtained capital proficiently (Jamali et al., 2008). The CG structure in place is the product of a firm's characteristics, its identity, the demands imposed on it by the stakeholders, and laws and regulations imposed by the authorities (De Graaf \& Herkströter, 2007). Evidence shows that effective CG boosts firm competitiveness, resulting in higher financial performance (Ho, 2005). The area of governance related to managerial entrenchment is the focus of the present study. As managers become more entrenched, they may tend to avoid long-term investments that stretch beyond their own tenures, and those with uncertain cash flows (Sheikh, 2018). The 'quiet life hypothesis' supports these findings by proposing that entrenched managers that are shielded from shareholder oversight may shirk from engaging in investment and other value creating activities that demand substantial executive time and attention (Chintrakarn et al., 2013; Ikeda et al., 2018). Firm value may ultimately be reduced from the avoidance of such investments (Bebchuk et al., 2009; Chang \& Zhang, 2015; Cremers \& Ferrell, 2014; Gompers et al., 2003).

To the degree that structural elements limit entrenchment, CSR engagement is expected to increase. CSR engagement can be beneficial to the firm in many respects. Examples are higher following and favorable security analysts' assessments (Ioannou \& Serafeim, 2015; Luo et al., 2015), favorable job seekers' perceptions of the firm (Jones et al., 2014), lower cost of capital (Sharfman \& Fernando, 2008), and lower capital constraints (Cheng et al., 2014). Some authors 
have also concluded that CSR provides "insurance-like" benefits against negative environmental events that threaten firm value (Godfrey et al., 2009; McGuire et al., 1988) and against litigation risk (Koh et al., 2014).

Research suggests that lower entrenchment can lead to better social and environmental performance (Malik, 2015) and lower incidences of irresponsibility (Arora \& Dharwadkar, 2011). Using a large longitudinal sample, Jo and Harjoto (2011) find that firms that restrain managerial entrenchment engage in more CSR activities than a matched sample of weaker-governance firms. Using the MSCI KLD dataset, Sheikh (2018), however, finds that the negative effect of entrenchment on CSR is only driven by CSR strengths, not CSR concerns. These findings suggest entrenched managers may lower CSR, but the opposite relationship has been reported by Harjoto and Jo (2011) concerning the over-investment hypothesis, wherein entrenched managers intent on building their personal reputations might over-invest in CSR to the detriment of shareholder wealth (see also Barnea \& Rubin, 2010). Thus, although evidence continues to accumulate, the relationship between managerial entrenchment and CSR remains an empirical question.

At the core of CG literature is the idea that better governance in the firm creates value for owners and reduces agency costs (Gompers et al., 2010). The corollary is that entrenchment increases agency costs and may reduce value creation, possibly limiting CSR engagement as well. Entrenchment bestows more power to managers and reduces shareholders' ability to exercise their will. Shareholders with sufficient latitude would presumably favor CSR engagement in order to resolve potential stakeholder conflicts and thereby increase firm value and performance (e.g. Harjoto \& Jo, 2011), whereas entrenched managers may resist such efforts. The foregoing leads to the following hypothesis:

H1 Managerial entrenchment is negatively related to CSR engagement.

\subsection{The moderating role of economic policy uncertainty}

Although we generally expect managerial entrenchment to have a negative impact on CSR engagement, changes in the level of economic policy uncertainty may give rise to different managerial behaviors concerning CSR. As stated previously, high levels of EPU are negatively associated with asset returns, firm-level investment, firm performance, firm acquisitiveness, and innovation activities (Bhattacharya et al., 2017; Brogaard \& Detzel, 2015; Chen et al., 2019; Gulen \& Ion, 2016; Kang et al., 2014; Muriithi et al., 2020; Nguyen \& Phan, 2017). Moreover, EPU has been positively related to the cost of external financing and firm cash holdings (Gilchrist et al., 2014; Phan et al., 2019). Unlike other types of uncertainty, EPU cannot be hedged through the actions of the firm since it is largely outside of the firm's control (Bonaime et al., 2018). As reflected in Fig. 1, our expectation is that the level of managerial entrenchment may influence CSR engagement in a manner that is different when EPU is at low versus high levels, for a variety of reasons.

In times of low policy uncertainty, outcomes of various investments are relatively easier to predict than in uncertain environments. Managers who are not entrenched 


\begin{tabular}{|l|l|}
\hline $\begin{array}{l}\text { - Environment: Unstable/Unpredictable } \\
\text { - Risk to investments: Higher } \\
\text { - Protections from entrenchment: Lower } \\
\text { - Shareholder oversight: Higher } \\
\text { - Expectation: Lower motivation for } \\
\text { CSR engagement. }\end{array}$ & $\begin{array}{l}\text { - Environment: Unstable/Unpredictable } \\
\text { - Risk to investments: Higher } \\
\text { - Protections from entrenchment: Higher } \\
\text { - Shareholder oversight: Higher } \\
\text { - Expectation: Higher motivation for } \\
\text { CSR engagement. }\end{array}$ \\
\hline $\begin{array}{l}\text { - Environment: Stable/Predictable } \\
\text { - Risk to investments: Lower } \\
\text { - Protections from entrenchment: Lower } \\
\text { - Shareholder oversight: Lower } \\
\text { - Expectation: Higher motivation for } \\
\text { CSR engagement. }\end{array}$ & $\begin{array}{l}\text { - Environment: Stable/Predictable } \\
\text { - Risk to investments: Lower } \\
\text { - Protections from entrenchment: Higher } \\
\text { - Shareholder oversight: Lower } \\
\text { - Expectation: Lower motivation for } \\
\text { CSR engagement. }\end{array}$ \\
Low Managerial Entrenchment
\end{tabular}

Fig. 1 Summary of proposed EPU-entrenchment scenarios and resultant CSR expectations

would likely pursue CSR engagements of a strategic nature, wherein managers invest in CSR with the aim of maximizing shareholder returns (Cespa \& Cestone, 2007). Because future outcomes are relatively predictable (compared to high-EPU environments), managers should be relatively less threatened regarding their future in the firm (Milliken \& Lant, 1991). Thus, managers with even low entrenchment could be confident that their informed CSR investments would not draw negative attention from shareholders. But if managers are more entrenched when EPU is low, their motivation to engage in CSR is expected to be relatively lower. First, not only does entrenchment offer safeguards to their likelihood of firm takeover or to their personal short-term losses, but their future positions in the firm are also not threatened given the relatively certain future outcomes. Second, and particularly when managers are entrenched, they are often motivated to maximize their perquisite consumption and individual benefits. Thus, when EPU is low, we would expect the CSR engagement of entrenched mangers to be lower than that of less-entrenched management.

On the other hand, when policy uncertainty rises, the risk to shareholders' wealth increases, potentially drawing more attention from active shareholders and analysts. Naturally, there would be significant repercussions to mangers that are perceived to have performed below par, with some having to defend themselves against ouster when financial outcomes are unmet. If protections afforded by entrenchment begin to weaken, entrenched managers who are keen on maintaining their positions may enhance relationships with various stakeholders to reduce the likelihood of being replaced (Surroca \& Tribó, 2008). Indeed, Pagano and Volpin (2005) propose that managers may find it beneficial to ally with employee groups, as well as enter into expensive social responsibility commitments to ward off corporate raiders. Increased CSR engagement may enable them to reduce adverse scrutiny from activist stakeholders who might appeal to the more powerful stakeholders to withhold resources and support for the firm (Frooman, 1999; Henriques \& Sadorsky, 1999; Reid \& Toffel, 2009). By engaging in CSR, 
entrenched managers are able to increase their firms' legitimacy (Goll \& Rasheed, 2004), further cementing their positions. Conversely, managers without the protection of entrenchment may find themselves more accountable to shareholders and the market for takeovers (Shelley, 2006) when EPU is high. For them, the increased difficulty in forecasting payoffs from investments, which also translates to a high likelihood of not meeting shareholder expectations, may be a demotivating factor for engaging in CSR. As a result, in an environment of high policy uncertainty, entrenched managers would be expected to have higher CSR engagement than managers who are less entrenched.

H2 Economic policy uncertainty moderates the relationship between managerial entrenchment and CSR engagement, such that higher uncertainty diminishes the negative relationship.

\section{Methods}

\subsection{Sample}

The measures were obtained from Bloomberg's ESG database and Compustat/ Capital IQ, while the entrenchment measure was constructed based on Bebchuk et al.'s (2009) entrenchment index (e-index). Sample collection began with all publicly traded U.S. firms that consistently appear in Bloomberg's ESG database for the years 2011-2018. Bloomberg collects environmental, social, and governance data from company-sourced filings such as corporate social responsibility reports, annual reports, company websites, and survey requests directly from companies. Financial measures were obtained from Bloomberg and Compustat/ Capital IQ databases. After excluding firms with missing data, a final sample of 386 firms representing 3,088 firm-year observations was obtained.

\subsection{Measures}

\subsubsection{Dependent variable: corporate social responsibility engagement}

The dependent variable, corporate social responsibility engagement, was obtained from Bloomberg's ESG database. The Bloomberg ESG rating scale ranges from 0 to 100 for each dimension (environmental, social, and governance) (hereafter referred to as CSR engagement). As our interest is in CSR engagement, we only utilize the environmental and social dimensions in our analysis. We exclude the governance dimension from analysis because (i) it is not a direct measure of CSR, and (ii) potential exists for multicollinearity with our entrenchment measure. Our aggregate CSR measure is obtained by a summation of the environment and social dimensions of the Bloomberg ESG database. 


\subsubsection{Independent variable: managerial entrenchment}

Our measurement of managerial entrenchment is calculated per Bebchuk et al.'s (2009) Entrenchment Index (E-index). This index has been used extensively in corporate governance studies in management, finance, economics, and accounting literature to measure the level of managerial entrenchment in firms. The index allocates one point for each of the following firm governance mechanisms for a range of zero to six: poison pills, classified boards, golden parachute provisions, shareholder restrictions on charter amendments, shareholder restrictions on bylaw amendments, and a supermajority requirement to approve a merger. We calculate the E-Index for all firms for which we have data from 2011-2018.

\subsubsection{Moderating variable: economic policy uncertainty}

Research on organizational environments traditionally has been characterized by two fundamentally different approaches to measurement - objective and perceptual measures (Boyd et al., 1993). Typically, objective environmental measures rely on archival sources and include indicators such as growth in industry sales and concentration ratios. Perceptual environmental measures, in comparison, entail the subjective judgments of the environment by organization members or key informants. Archival measures are useful for describing constraints (e.g. market structures) that are faced by all firms in an industry (Bourgeois, 1980). This study relied on an objective measure of economic policy uncertainty-the Baker et al. (2016) policy uncertainty index (hereafter, BBDI). This index has been extensively used in the finance and economics literature as a representative indicator of uncertainty in the policy environment (e.g. Gulen \& Ion, 2016; Hadani et al., 2017). The measure is constructed as a weighted average measure of (i) the frequency of newspaper articles related to policy uncertainty, (ii) uncertainty about future federal tax code changes, and (iii) dispersion in economic forecasts of government spending and the consumer price index, which represent fiscal and monetary policy uncertainty. For purposes of this study, the BBDI is advantageous in that it objectively quantifies EPU dimensions, decreasing concerns of bias and validity inherent in perceptual measures of uncertainty (Buchko, 1994).

\subsubsection{Control variables}

We include control variables that could influence the relationships we propose. These variables and their description are presented in Table 1.

\subsection{Statistical methods}

A panel dataset was used to test the hypotheses as panel data analysis overcomes the limitations associated with cross-sectional data (Beck \& Katz, 1995; 
Table 1 Control variables

\begin{tabular}{ll}
\hline Variable & Description \\
\hline Firm size & Natural log of total assets \\
Debt ratio & Long-term debt divided by total assets \\
Prior performance & Average ROA for the three years prior to the focal year \\
Organizational slack & Natural log of total cash and equivalents \\
Year effects & Year dummies for each of the sampling years \\
Advertising intensity & Advertising expenditures divided by net sales \\
Firm age & Total number of years the firm has been in existence \\
Industry effects & Dummies for the two-digit industry SIC code \\
\hline
\end{tabular}

Certo \& Semadeni, 2006). First, granted that firms and their shareholders are by nature idiosyncratic, panel analysis helps to overcome coefficient bias arising from unobserved heterogeneity and omitted variables. Second, panel data models are better suited than cross-sectional data for studying the dynamics of change. Finally, panel data can minimize the effects of aggregation bias that might arise from aggregating firms into broad groups such as by industry. The variables were tested for normality with the Skewness-Kurtosis test (sktest) in STATA and all were found to be normally distributed.

\section{Empirical results}

Descriptive statistics and correlations are presented in Table 2. Although intercorrelations among the various control variables were low, some were statistically significant, suggesting the potential for multicollinearity. Accordingly, the variance inflation factors (VIF) were calculated for the independent variables. The estimated VIF values were all less than 10 , with an average of 1.40 , indicating an absence of multicollinearity among the variables.

The first hypothesis proposes that managerial entrenchment is negatively related to CSR engagement. With the E-index, a lower value indicates a lower level of entrenchment, and vice versa. This relationship is tested in Table 3, model 2 and is found to be negative and significant $(-2.64 ; p<.05)$, supporting H1. The result seems to indicate that entrenched managers that are more powerful are likely to resist CSR engagement. This is consistent with the 'quiet life hypothesis' proposal that entrenched managers may shirk from engaging in value creating activities that demand substantial executive time and attention (Chintrakarn et al., 2013; Ikeda et al., 2018) such as CSR investment, which may ultimately reduce firm value.

EPU's moderating effect on the relationship between managerial entrenchment and CSR engagement is tested in Model 3. The coefficient of the interaction effect is positive and significant $(.02 ; p<.1)$, lending support to Hypothesis 2 . It is worth noting that the interaction effect is positive and significant, despite the individual 


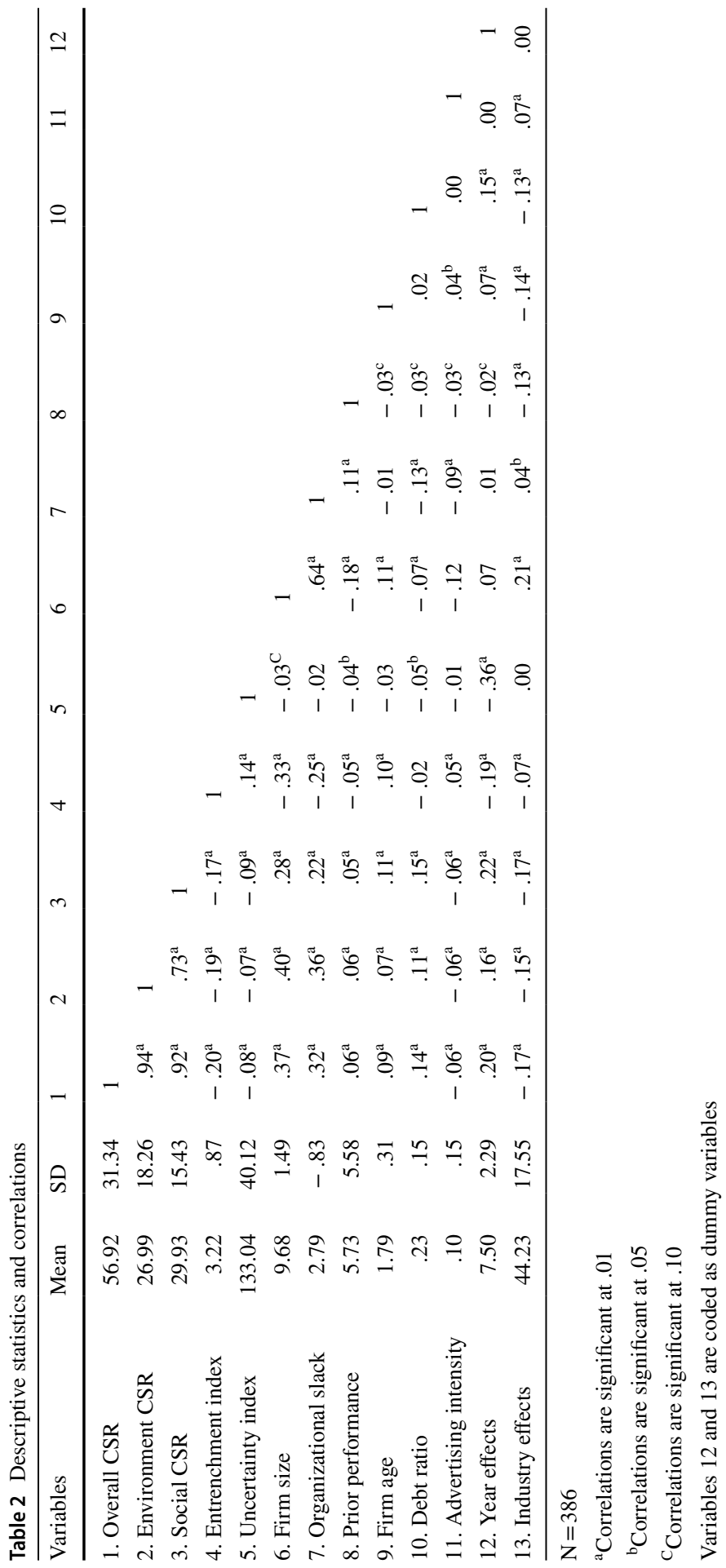


Table 3 Panel data results

\begin{tabular}{llll}
\hline DV & \multicolumn{2}{l}{ Overall CSR } \\
\cline { 2 - 4 } & M1 & M2 & M3 \\
\hline Control variables & & & \\
Firm size & $9.32^{* * *}$ & $8.71^{* * *}$ & $8.68^{* * *}$ \\
Debt ratio & 1.34 & .47 & .33 \\
Prior average ROA & .11 & .07 & .07 \\
Slack & $3.99 * *$ & $3.88^{* *}$ & $3.92^{* *}$ \\
Advertising intensity & 6.26 & 5.72 & 5.73 \\
Firm age & 3.85 & 4.83 & 4.84 \\
Year effects & Yes & Yes & Yes \\
Industry effect & Yes & Yes & Yes \\
Independent variables & & & \\
Entrenchment index & & $-2.64 * *$ & $-5.49 * *$ \\
Uncertainty index & & $-.67 * * *$ & $-.75^{* * *}$ \\
Entrenchment $\times$ uncertainty & & & $.02 *$ \\
Constant & -14.10 & $126.66^{* * *}$ & $139.21^{* * *}$ \\
$R^{2}$ & .44 & .44 & .45 \\
\hline N=386. $p<.10, * * p .05, * * *<.01$ & & \\
\hline
\end{tabular}

effects of the e-index and economic uncertainty being negative. To further understand this effect, an interaction plot was created for two levels of uncertainty, low (minus one standard deviation from the mean), and high (plus one standard deviation from the mean). Figure 2 indicates that at low levels of uncertainty, CSR engagement decreases as entrenchment increases, while at high levels of uncertainty, such engagement decreases albeit at a lower rate, as entrenchment increases. Together, these results portray the main effect of stronger governance-characterized by low entrenchment-enhancing CSR engagement, whereas the interaction indicates that as uncertainty increases, managerial entrenchment's negative impact on CSR engagement is diminished.

\subsection{Supplementary analysis}

To this point, the discussion has been framed in the context of an aggregate level of CSR engagement obtained by summing Bloomberg's environmental and social CSR dimensions into a single indicator. Although separate hypotheses have not been proposed, it is possible that managers may focus more on a particular CSR dimension depending on their degree of entrenchment and the level of uncertainty. Table 4 presents the results of supplementary analysis performed on each of the two dimensions to illuminate the relationships under study for each dimension.

Tests of the environmental CSR engagement are reported in Table 4, models M1-M3. Results indicate that environmental CSR engagement is significantly 


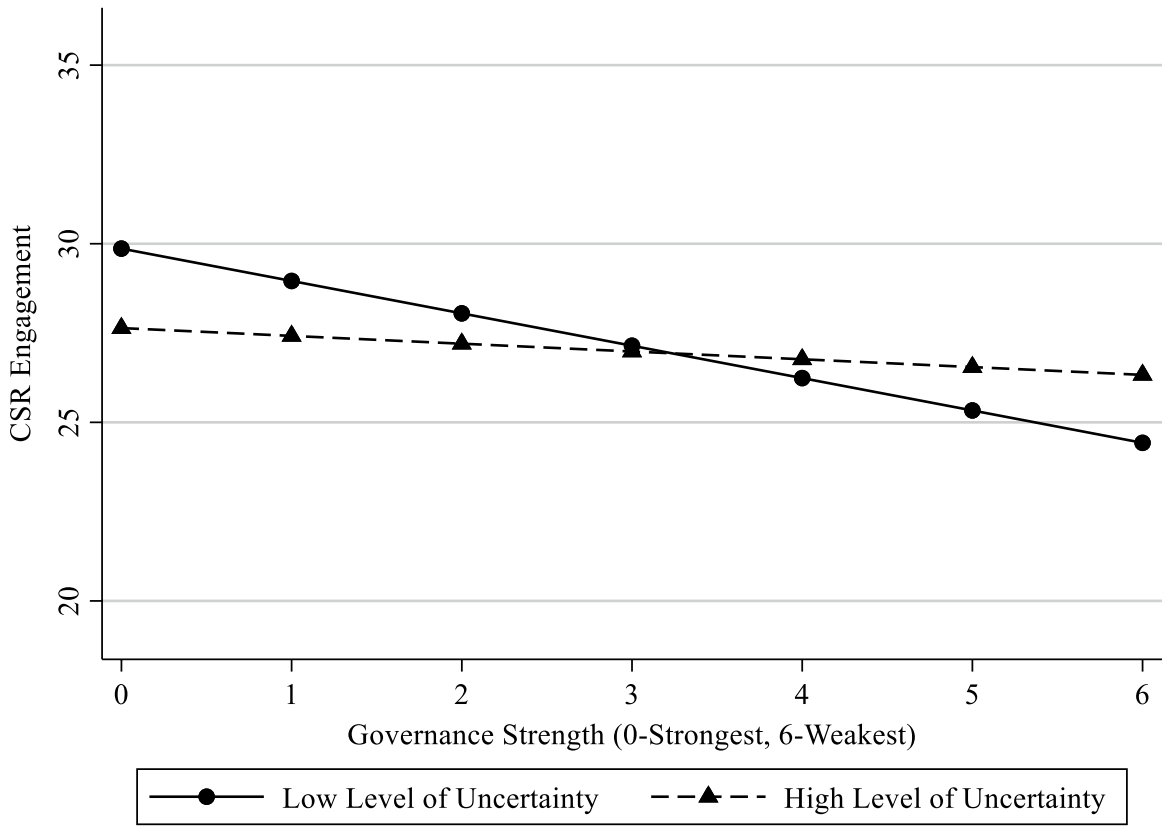

Fig. 2 Moderating effect of uncertainty on the managerial entrenchment-corporate social responsibility relationship

Table 4 Supplemental analysis

\begin{tabular}{|c|c|c|c|c|c|c|}
\hline \multirow[t]{2}{*}{ DV } & \multicolumn{3}{|c|}{ Environmental CSR } & \multicolumn{3}{|c|}{ Social CSR } \\
\hline & M1 & M2 & M3 & M4 & M5 & M6 \\
\hline \multicolumn{7}{|l|}{ Control variables } \\
\hline Firm size & $6.03 * * *$ & $5.70 * * *$ & $5.67 * * *$ & $3.29 * * *$ & $3.01 * * *$ & $3.00^{* * *}$ \\
\hline Debt ratio & 2.74 & 2.27 & 2.17 & -1.40 & -1.80 & -1.84 \\
\hline Prior average ROA & .05 & .02 & .02 & .07 & .05 & .05 \\
\hline Slack & 1.81 & 1.75 & 1.77 & $2.18 * *$ & $2.13 * *$ & $2.14 * *$ \\
\hline Advertising intensity & 4.79 & 4.50 & 4.50 & 1.47 & 1.23 & 1.23 \\
\hline Firm age & .82 & 1.35 & 1.36 & 3.03 & 3.48 & $3.48^{*}$ \\
\hline Year effects & yes & yes & yes & yes & yes & yes \\
\hline Industry effect & yes & yes & yes & yes & yes & yes \\
\hline \multicolumn{7}{|l|}{ Independent variables } \\
\hline Entrenchment index & & $-1.44 *$ & $-3.40 * * *$ & & $-1.20^{*}$ & -2.09 \\
\hline Uncertainty index & & $-.27 * * *$ & $-.33^{* * *}$ & & $-.40 * * *$ & $-.43 * * *$ \\
\hline Entrenchment $\times$ uncertainty & & & $.01 * *$ & & & .01 \\
\hline Constant & $-16.43 * * *$ & $42.11 * * *$ & $5.73^{* * *}$ & 2.33 & $84.56 * * *$ & $88.48 * * *$ \\
\hline $\mathrm{R}^{2}$ & .43 & .44 & .44 & .38 & .38 & .38 \\
\hline
\end{tabular}

$\mathrm{N}=386$

$* p<.10,{ }^{* *} p<.05, * * * p<.01$ 
negatively related to managerial entrenchment in model M2 $(-1.44 ; p<.1)$. The entrenchment $\times$ uncertainty interaction term in M3 is significant and positive (.01; $p<.05)$, suggesting that entrenched managers may engage in higher environmentrelated CSR when uncertainty levels are higher in order to ingratiate themselves to environmental stakeholders and possibly receive support from such activists (Surroca \& Tribó, 2008).

The social dimension is tested in Table 4, models M4-M6. Results indicate that social CSR engagement is negatively and significantly related to managerial entrenchment in model M5 $(-1.20 ; p<.10)$. This may suggest that more entrenched managers hold social CSR engagement in lesser regard and vice versa. The interaction term is not significant (M6), suggesting that the level of EPU does not affect the relationship.

To test for robustness of our results, we re-estimated our models using philanthropic donations (scaled by sales) as the dependent variable (e.g. Cheng et al., 2016). The results remained unchanged with this alternative measure.

\section{Discussion and conclusion, and future research}

This study drew on the behavioral theory of corporate governance to examine the relationship between managerial entrenchment and CSR engagement, and the potential moderating influence of economic policy uncertainty. Scholarly interest in the entrenchment-CSR connection has resulted in the investigation of numerous firmlevel factors (e.g. Arora \& Dharwadkar, 2011; Barnea \& Rubin, 2010; Jo \& Harjoto, 2011; Kachouri et al., 2020; Malik, 2015; Surroca \& Tribó, 2008) and a consideration of institutional contexts (e.g. Salehi et al., 2020; Surroca et al., 2020). Economic policy uncertainty is arguably an important institutional factor affecting strategic decision makers and organizational outcomes. As previously argued, outcomes such as firm performance (e.g. Brogaard \& Detzel, 2015; Muriithi et al., 2020), innovation activities (Bhattacharya et al., 2017) and acquisitions (Nguyen \& Phan, 2017) are affected by EPU levels. Thus, EPU apparently has a pervasive impact on a variety of organizational phenomena.

In the current study, higher levels of managerial entrenchment were found to be associated with lower CSR engagement. Bebchuk and colleagues (2009) previously found increased managerial entrenchment was related to lower firm valuation and substantial negative abnormal returns. Overall, CSR engagement likewise appears to decrease in the context of weaker governance. Additionally, economic policy uncertainty was proposed to exhibit a moderating influence on the relationship between governance strength and CSR engagement. EPU was indeed found to moderate this relationship, such that increases in policy uncertainty appear to diminish the negative impact of entrenchment on CSR engagement. At low levels of EPU, entrenched managers appear to engage in significantly less CSR than their less entrenched counterparts. Under conditions of high EPU, however, although more entrenched managers appear to engage in less CSR, such engagement is lower than CSR engagement by less entrenched managers. 
The question arises-What might account for the differences in CSR engagement under high vs low EPU? One possibility is that by maintaining CSR at a slightly lower level when EPU is high, entrenched managers are able to avoid adverse scrutiny from activist stakeholders, who might otherwise appeal to the more powerful stakeholders to withhold resources and support for the firm (Frooman, 1999; Henriques \& Sadorsky, 1999; Reid \& Toffel, 2009). Entrenched managers are also able to ward off stakeholders that may threaten their positions in their firms (Milliken \& Lant, 1991). Maintaining CSR engagement during times when EPU is high may also increase their firms' social legitimacy (Goll \& Rasheed, 2004) and gain insurance-like benefits (Godfrey et al., 2009) from negative policy uncertainty effects that could threaten firm value.

Our supplementary analysis indicates that managers may be inclined to concentrate on a particular aspect of CSR engagement depending on the level of EPU. Indeed, findings suggest that as EPU increases, entrenched managers may engage in higher environment-related CSR, perhaps to ingratiate themselves to environmental stakeholders and possibly receive support from such activists (Surroca \& Tribó, 2008). This is in stark contrast to social CSR, for which results suggested that the level of engagement is unaffected by EPU. Taken together, these findings may indicate that specific CSR dimensions could be perceived to yield unique benefits depending on the level of policy uncertainty.

Our study contributes to CG and CSR literature in a number of ways. It highlights the importance of EPU in managerial decision-making, pointing to the environmental context as a principal factor in CG-CSR discourse. Although agency and stewardship theories are prominent in CG-CSR dialogue, these theoretical perspectives are not a panacea for all CG-CSR inquiry. Novel theoretical perspectives may advance our understanding of this relationship, especially when considering the environmental context. By employing the behavioral theory of corporate governance, we hope to advance this discourse. The interactive effect of EPU and entrenchment appears to influence CSR engagement aimed at satisfying numerous stakeholders. If policy uncertainty's impact on CSR engagement depends on the degree of managerial entrenchment, other critical firm-level actions could also be influenced by consideration of entrenchment as well. Examples might include firm-level investment (Chen et al., 2019; Gulen \& Ion, 2016; Kang et al., 2014), acquisition activity (Nguyen \& Phan, 2017), and innovation (Bhattacharya et al., 2017). The inclusion of entrenchment along with EPU may represent fruitful areas for future research on corporate and societal outcomes.

This study's findings underscore the importance of good governance as an antecedent to positive outcomes for the firm and society. In line with prior research (e.g. Arora \& Dharwadkar, 2011; Jo \& Harjoto, 2011; Malik, 2015), good governance-characterized by low entrenchment, appears to be associated with more CSR engagement when EPU is low. Firms that value CSR engagement may generally be better served by having management structures that do not facilitate managerial entrenchment. Boards of directors can affect the degree of entrenchment through their approach to issues such as staggered boards, golden parachutes, anti-takeover provisions, and CEO/board chair separation, among others. At a broader level of governance, government policy makers might be instrumental in reducing policy 
uncertainty to the extent that they can be transparent and provide sufficient cues to future intentions. This study's findings indicate that such efforts might influence not only CSR engagement, but potentially other desirable corporate and societal outcomes such as firm-level investment, financial reporting quality, acquisition performance, and innovation.

In the context of varying levels of EPU, the establishment of specific governance structures may be beneficial to varying degrees. Optimal configurations of governance mechanisms in light of EPU could be illuminating for boards of directors. In addition, the efficacy of strong governance in enhancing CSR could in part depend on the degree to which managers see themselves as stewards versus agents (Davis et al., 1997). Another avenue is to examine the governance-CSR link in light of institutional differences. Given that different institutional contexts are characterized by varying norms, further research could help uncover how EPU affects approaches to CSR across different contexts. In addition, this study only concentrated on one type of uncertainty - environmental policy uncertainty. Investigations could include other types of uncertainty (e.g. technological uncertainty, behavioral uncertainty, task uncertainty) and their possible effects on CSR engagement.

This study has a number of limitations. Bloomberg ESG scores are objective measures that may not always accurately match stakeholders' perceptions of a firm's social performance. Also, the sample was comprised of a variety of industries, favoring generalizability over precision. Single-industry studies or comparisons of effects between industries could reveal whether certain governance mechanisms differ in their effects on CSR depending on the industry. Finally, policy uncertainty is an objective measure demonstrated to be broadly consequential to investment decisions, particularly for firms contemplating irreversible investments or dependent on government spending (Baker et al., 2016). A breakdown of these categories might help reveal best practices for governance and CSR in these contexts. Another extension of this work could include uncertainty measures that tap into the environmental perceptions of executives within organizations. These often diverge from objective measures (Boyd et al., 1993) and may reflect executives' intentions regarding optimal CSR engagement.

\section{References}

Altig, D., Baker, S., Barrero, J. M., Bloom, N., Bunn, P., Chen, S., Davis, S., Leather, J., Meyer, B., Mihaylov, E., Mizen, P., Parker, N., Renault, T., Smietanka, P., \& Thwaites, G. (2020). Economic uncertainty before and during the COVID-19 pandemic. Journal of Public Economics, 191(2020), 104274.

Arora, P., \& Dharwadkar, R. (2011). Corporate governance and corporate social responsibility (CSR): The moderating roles of attainment discrepancy and organization slack. Corporate Governance: An International Review, 19(2), 136-152.

Baker, S. R., Bloom, N., \& Davis, S. J. (2016). Measuring economic policy uncertainty. The Quarterly Journal of Economics, 131(4), 1593-1636.

Barnea, A., \& Rubin, A. (2010). Corporate social responsibility as a conflict between shareholders. Journal of Business Ethics, 97(1), 71-86. 
Barnett, M. L. (2007). Stakeholder influence capacity and the variability of financial returns to corporate social responsibility. Academy of Management Review, 32(3), 794-816.

Bebchuk, L., Cohen, A., \& Ferrell, A. (2009). What matters in corporate governance? The Review of Financial Studies, 22(2), 783-827.

Beck, N., \& Katz, J. N. (1995). What to do (and not to do) with time-series cross-section data. American Political Science Review, 89(3), 634-647.

Bhattacharya, U., Hsu, P. H., Tian, X., \& Xu, Y. (2017). What affects innovation more: Policy or policy uncertainty? Journal of Financial and Quantitative Analysis, 52(5), 1869-1901.

Bonaime, A., Gulen, H., \& Ion, M. (2018). Does policy uncertainty affect mergers and acquisitions? Journal of Financial Economics, 129(3), 531-558.

Bourgeois, L. J., III. (1980). Performance and consensus. Strategic Management Journal, 1(3), 227-248.

Boyd, B. K., Dess, G. G., \& Rasheed, A. M. (1993). Divergence between archival and perceptual measures of the environment: Causes and consequences. Academy of Management Review, 18(2), 204-226.

Brogaard, J., \& Detzel, A. (2015). The asset-pricing implications of government economic policy uncertainty. Management Science, 61(1), 3-18.

Buchko, A. A. (1994). Conceptualization and measurement of environmental uncertainty: An assessment of the Miles and Snow perceived environmental uncertainty scale. Academy of Management Journal, 37(2), 410-425.

Carroll, A. (1979). A three-dimensional conceptual model of corporate social performance. Academy of Management Review, 4, 497-505.

Certo, S. T., \& Semadeni, M. (2006). Strategy research and panel data: Evidence and implications. Journal of Management, 32, 449-471.

Cespa, G., \& Cestone, G. (2007). Corporate social responsibility and managerial entrenchment. Journal of Economics \& Management Strategy, 16, 741-771.

Chang, X., \& Zhang, H. F. (2015). Managerial entrenchment and firm value: A dynamic perspective. Journal of Financial and Quantitative Analysis, 50, 1083-1103.

Chen, P. F., Lee, C. C., \& Zeng, J. H. (2019). Economic policy uncertainty and firm investment: Evidence from the US market. Applied Economics, 51, 3423-3435.

Cheng, B., Ioannou, I., \& Serafeim, G. (2014). Corporate social responsibility and access to finance. Strategic Management Journal, 35(1), 1-23.

Cheng, S., Lin, K. Z., \& Wong, W. (2016). Corporate social responsibility reporting and firm performance: evidence from China. Journal of Management \& Governance, 20(3), 503-523.

Chintrakarn, P., Jiraporn, N., \& Jiraporn, P. (2013). The effect of entrenched boards on corporate risktaking: testing the quiet life hypothesis. Applied Economics Letters, 20(11), 1067-1070.

Cremers, M., \& Ferrell, A. (2014). Thirty years of shareholder rights and firm value. The Journal of Finance, 69(3), 1167-1196.

Davis, J. H., Schoorman, F. D., \& Donaldson, L. (1997). Toward a stewardship theory of management. Academy of Management Review, 22(1), 20-47.

Davis, K. (1973). The case for and against business assumption of social responsibilities. Academy of Management Journal, 16, 312-322.

De Graaf, F. J., \& Herkströter, C. A. (2007). How corporate social performance is institutionalised within the governance structure. Journal of Business Ethics, 74(2), 177-189.

Delios, A., \& Henisz, W. J. (2003). Political hazards, experience, and sequential entry strategies: The international expansion of Japanese firms, 1980-1998. Strategic Management Journal, 24(11), 1153-1164.

Dess, G. G., \& Beard, D. W. (1984). Dimensions of organizational task environments. Administrative Science Quarterly, 29(1), 52-73.

Flammer, C., Hong, B., \& Minor, D. (2019). Corporate governance and the rise of integrating corporate social responsibility criteria in executive compensation: Effectiveness and implications for firm outcomes. Strategic Management Journal, 40(7), 1097-1122.

Frederick, W. (1986). Toward CSR3: Why ethical analysis is indispensable and unavoidable in corporate affairs. California Management Review, 18(2), 126-141.

Friedman, M. (1970). The Social Responsibility of Business is to Increase its Profits. The New York Times Magazine, September 13.

Frooman, J. (1999). Stakeholder influence strategies. Academy of Management Review, 24(2), 191-205. 
García-Sánchez, I. M., Hussain, N., Khan, S. A., \& Martínez-Ferrero, J. (2020). Managerial entrenchment, corporate social responsibility, and earnings management. Corporate Social Responsibility and Environmental Management, 27(4), 1818-1833.

Gennari, F., \& Salvioni, D. M. (2019). CSR committees on boards: The impact of the external country level factors. Journal of Management \& Governance, 23(3), 759-785.

Gilchrist, S., Sim, J. W., \& Zakrajšek, E. (2014). Uncertainty, Financial Frictions, and Investment Dynamics. National Bureau of Economic Research, Inc. Working Papers, 20038.

Godfrey, P. C., Merrill, C. B., \& Hansen, J. M. (2009). The relationship between corporate social responsibility and shareholder value: An empirical test of the risk management hypothesis. Strategic Management Journal, 30(4), 425-445.

Goll, I., \& Rasheed, A. A. (2004). The moderating effect of environmental munificence and dynamism on the relationship between discretionary social responsibility and firm performance. Journal of Business Ethics, 49, 41-54.

Gompers, P., Ishii, J., \& Metrick, A. (2003). Corporate governance and equity prices. The Quarterly Journal of Economics, 118(1), 107-156.

Gompers, P. A., Ishii, J., \& Metrick, A. (2010). Extreme governance: An analysis of dual-class firms in the United States. The Review of Financial Studies, 23(3), 1051-1088.

Gourevitch, P. A., \& Shinn, J. (2005). Political Power and Corporate Control: The New Global Politics of Corporate Governance. Princeton University Press.

Gulen, H., \& Ion, M. (2016). Policy uncertainty and corporate investment. The Review of Financial Studies, 29(3), 523-564.

Hadani, M., Bonardi, J. P., \& Dahan, N. M. (2017). Corporate political activity, public policy uncertainty, and firm outcomes: A meta-analysis. Strategic Organization, 15(3), 338-366.

Harjoto, M. A., \& Jo, H. (2011). Corporate governance and CSR nexus. Journal of Business Ethics, $100(1), 45-67$.

Heal, G. (2005). Corporate social responsibility: An economic and financial framework. The Geneva Papers on Risk and Insurance, 30(3), 387-409.

Henriques, I., \& Sadorsky, P. (1999). The relationship between environmental commitment and managerial perceptions of stakeholder importance. Academy of Management Journal, 42(1), 87-99.

Ho, C. K. (2005). Corporate governance and corporate competitiveness: An international analysis. Corporate Governance: An International Review, 13(2), 211-253.

Ikeda, N., Inoue, K., \& Watanabe, S. (2018). Enjoying the quiet life: Corporate decision-making by entrenched managers. Journal of the Japanese and International Economies, 47, 55-69.

Ioannou, I., \& Serafeim, G. (2015). The impact of corporate social responsibility on investment recommendations: Analysts' perceptions and shifting institutional logics. Strategic Management Journal, 36(7), 1053-1081.

Jamali, D., Safieddine, A. M., \& Rabbath, M. (2008). Corporate governance and corporate social responsibility synergies and interrelationships. Corporate Governance: An International Review, 16(5), 443-459.

Jensen, M. C., \& Meckling, W. H. (1976). Theory of the firm: Managerial behavior, agency costs and ownership structure. Journal of Financial Economics, 3(4), 305-360.

Jeong, N. (2020). The impact of two types of CEO overcompensation on corporate social responsibility. Journal of Management \& Governance, 24, 749-767.

Jo, H., \& Harjoto, M. A. (2011). Corporate governance and firm value: The impact of corporate social responsibility. Journal of Business Ethics, 103(3), 351-383.

Jones, D. A., Willness, C. R., \& Madey, S. (2014). Why are job seekers attracted by corporate social performance? Experimental and field tests of three signal-based mechanisms. Academy of Management Journal, 57(2), 383-404.

Kachouri, M., Salhi, B., \& Jarboui, A. (2020). The impact of gender diversity on the relationship between managerial entrenchment and corporate social responsibility: Evidence from UK companies. Journal of Global Responsibility.

Kaczmarek, S. (2017). Rethinking board diversity with the behavioural theory of corporate governance: Opportunities and challenges for advances in theorising. Journal of Management \& Governance, 21(4), 879-906.

Kang, W., Lee, K., \& Ratti, R. A. (2014). Economic policy uncertainty and firm-level investment. Journal of Macroeconomics, 39, 42-53.

Keats, B. W., \& Hitt, M. A. (1988). A causal model of linkages among environmental dimensions, macro organizational characteristics, and performance. Academy of Management Journal, 31(3), 570-598. 
Koh, P. S., Qian, C., \& Wang, H. (2014). Firm litigation risk and the insurance value of corporate social performance. Strategic Management Journal, 35(10), 1464-1482.

Le, S., Fuller, B., Muriithi, S., Walters, B., \& Kroll, M. J. (2015). The influence of top managers' values on corporate social performance: A meta-analysis. Journal of Managerial Issues, 27(1-4), 9-27.

Luo, X., Wang, H., Raithel, S., \& Zheng, Q. (2015). Corporate social performance, analyst stock recommendations, and firm future returns. Strategic Management Journal, 36(1), 123-136.

Mackey, A., Mackey, T. B., \& Barney, J. B. (2007). Corporate social responsibility and firm performance: Investor preferences and corporate strategies. Academy of Management Review, 32(3), 817-835.

Malik, M. (2015). Value-enhancing capabilities of CSR: A brief review of contemporary literature. Journal of Business Ethics, 127(2), 419-438.

Mazar, N., \& Ariely, D. (2006). Dishonesty in everyday life and its policy implications. Journal of Public Policy \& Marketing, 25(1), 117-126.

McGuire, J. B., Sundgren, A., \& Schneeweis, T. (1988). Corporate social responsibility and firm financial performance. Academy of Management Journal, 31(4), 854-872.

McWilliams, A., \& Siegel, D. (2001). Corporate social responsibility: A theory of the firm perspective. Academy of Management Review, 26(1), 117-127.

Milliken, F., \& Lant, T. (1991). The effect of an organization's recent performance history on strategic persistence and change: The role of managerial interpretations. In J. Dutton, A. Huff, \& P. Shrivastava (Eds.), Advances in Strategic Management (pp. 125-152). JAI Press.

Muriithi, S., Walters, B., \& Gilley, O. (2020). Corporate social responsibility engagement, economic policy uncertainty, and firm financial performance. Journal of Business Strategies, 37(2), 1-21.

Nguyen, N. H., \& Phan, H. V. (2017). Policy uncertainty and mergers and acquisitions. Journal of Financial and Quantitative Analysis, 52(2), 613-644.

Nilavongse, R., Michał, R., \& Uddin, G. S. (2020). Economic policy uncertainty shocks, economic activity, and exchange rate adjustments. Economics Letters, 186(2020), 108765.

Pagano, M., \& Volpin, P. F. (2005). Managers, workers, and corporate control. The Journal of Finance, $60(2), 841-868$.

Pfeffer, J., \& Salancik, G. (1978). The external control of organizations: A resource-dependence perspective. Harper \& Row.

Phan, H. V., Nguyen, N. H., Nguyen, H. T., \& Hegde, S. (2019). Policy uncertainty and firm cash holdings. Journal of Business Research, 95, 71-82.

Porter, M. E., \& Kramer, M. R. (2006). The link between competitive advantage and corporate social responsibility. Harvard Business Review, 84(12), 78-92.

Reid, E. M., \& Toffel, M. W. (2009). Responding to public and private politics: Corporate disclosure of climate change strategies. Strategic Management Journal, 30(11), 1157-1178.

Salehi, M., Mahmoudabadi, M., Adibian, M. S., \& Ranjbar, H. R. (2020). The potential impact of managerial entrenchment on firms' corporate social responsibility activities and financial performance: Evidence from Iran. International Journal of Productivity and Performance Management.

Sharfman, M. P., \& Fernando, C. S. (2008). Environmental risk management and the cost of capital. Strategic Management Journal, 29(6), 569-592.

Sheikh, S. (2018). Is corporate social responsibility a value-increasing investment? Evidence from antitakeover provisions. Global Finance Journal, 38, 1-12.

Shelley, S. M. (2006). Entrenched managers \& corporate social responsibility. Penn State Law Review, 111(1), 107-136.

Surroca, J. A., Aguilera, R. V., Desender, K., \& Tribó, J. A. (2020). Is managerial entrenchment always bad and corporate social responsibility always good? A cross-national examination of their combined influence on shareholder value. Strategic Management Journal, 41(5), 891-920.

Surroca, J., \& Tribó, J. A. (2008). Managerial entrenchment and corporate social performance. Journal of Business Finance \& Accounting, 35(5-6), 748-789.

Tan, J., \& Tan, D. (2005). Environment-strategy co-evolution and co-alignment: A staged model of Chinese SOEs under transition. Strategic Management Journal, 26(2), 141-157.

Tversky, A., \& Kahneman, D. (1978). Judgment under uncertainty, heuristics and biases: Biases in judgments reveal some heuristics of thinking under uncertainty. In P. Diamond \& M. Rothschild (Eds.), Uncertainty in Economics (pp. 17-34). Academic Press.

Westphal, J. D., \& Zajac, E. J. (2013). A behavioral theory of corporate governance: Explicating the mechanisms of socially situated and socially constituted agency. The Academy of Management Annals, 7(1), 607-661. 
Wood, D. (1991). Corporate social performance revisited. Academy of Management Review, 16, 691-718.

Yung, K., \& Root, A. (2019). Policy uncertainty and earnings management: International evidence. Journal of Business Research, 100, 255-267.

Publisher's Note Springer Nature remains neutral with regard to jurisdictional claims in published maps and institutional affiliations.

Sammy G. Muriithi, is an assistant professor of Management in the College of Business at the University of Central Oklahoma. His primary areas of research interest include corporate social responsibility and sustainability, corporate governance, mergers and acquisitions, and family business.

Bruce A. Walters is the Edward L. Moyers Endowed Professor in the Department of Management in the College of Business at Louisiana Tech University. His teaching, research, and consulting interests include corporate governance, acquisitions, strategic decision processes, top executive characteristics, and corporate social responsibility. His research has appeared in several journals, including Academy of Management Journal, Strategic Management Journal, Journal of Management, Strategic Organization, Journal of Business Ethics, and Journal of Business Research.

William R. McCumber, PhD, is the JPJ Investments Endowed and Associate Professor of Finance at the College of Business at Louisiana Tech University.

Luis R. Robles is an MBA graduate of the College of Business at the University of Central Oklahoma. His research is in the areas of corporate social responsibility and sustainability, corporate governance, mergers and acquisitions, and organizational performance.

\section{Authors and Affiliations}

\section{Sammy G. Muriithi ${ }^{1}$ - Bruce A. Walters ${ }^{2}$. William R. McCumber ${ }^{3}$. Luis R. Robles $\mathrm{Sr}^{4}$}

Bruce A. Walters

bwalters@latech.edu

William R. McCumber

mccumber@latech.edu

Luis R. Robles Sr.

lrobles@uco.edu

1 Department of Management, College of Business, University of Central Oklahoma, 100 North University Drive, PO Box 115, Edmond, OK 73034, USA

2 Department of Management, College of Business, Louisiana Tech University, PO Box 10318, Ruston, LA 71272, USA

3 Department of Economics and Finance, College of Business, Louisiana Tech University, PO Box 10318, Ruston, LA 71272, USA

4 Department of Military Science, College of Business, University of Central Oklahoma, 100 North University Drive, Edmond, OK 73034, USA 